\title{
Blood Biochemical Components and Progesterone Hormone on Day of Estrus in Crossbred Cattle in Egypt
}

\author{
Mourad RS \\ Animal Production Department, Faculty of Agriculture, Menufiya University, Egypt \\ E-mail: efaidallah@gmail.com \\ (received 23-08-2018; revised 05-09-2018; accepted 20-09-2018)
}

\begin{abstract}
ABSTRAK
Mourad RS. 2018. Komponen biokimia darah dan hormon progesteron pada estrus sapi persilangan di Mesir. JITV 23(3): 103111. DOI: http://dx.doi.org/10.14334/jitv.v23i3.1855

Kekurangan atau kelebihan mineral seperti $\mathrm{P}, \mathrm{Cu}$ dan $\mathrm{Zn}$ dikaitkan dengan kesuburan subnormal dan kondisi anoestrus. Penelitian ini dilakukan di unit veteriner pada 18 betina sapi persilangan yang dipilih secara acak pada saat estrus (kelompok estrus) dan sebagai control dipilih 14 ekor sapi persilangan dari sapi-sapi yang baru beranak sekitar 6 - 12 jam (kelompok kontrol). Tujuan penelitian ini adalah untuk mempelajari komponen biokimia dan hormon progesteron pada hari estrus dari sapi persilangan di Mesir, informasi dari penelitian ini akan digunakan untuk mengkonfirmasi terjadinya estrus untuk meningkatkan persentasi keberhasilan perkawinan. Dalam plasma darahnya, konsentrasi semua komponen biokimia dan konsentrasi progesteron pada ternak yang estrus lebih tinggi daripada sapi kontrol kecuali globulin. Dari Sapi control didapatkan kosentrasi Mg, Ca / P ratio, Co, Cu, Zn, Se, dan Mo yang lebih tinggi dari pada sapi estrus. Di sisi lain, konsentrasi plasma darah Na, K, Ca, P, Mn, dan Fe lebih tinggi pada sapi estrus daripada pada sapi kontrol. Konsentrasi progesteron sapi estrus lebih rendah saat musim panas daripada disaat musim dingin. Pada sapi estrus, semua unsur makro plasmanya lebih tinggi disaat musim dingin daripada dimusim panas kecuali rasio K, Ca dan Ca/P. Selanjutnya pada sapi estrus, semua unsur mikro plasma darahnya lebih tinggi disaat musim dingin dibandingkan saat musim panas kecuali Zn, Mn, Se, dan Fe.
\end{abstract}

Kata Kunci: Sapi, Glukosa, Kolesterol, Mineral, Progesteron

\section{ABSTRACT}

Mourad RS. 2018. Blood biochemical components and progesterone hormone on day of estrus in crossbred cattle in Egypt. JITV 23(3): 103-111. DOI: http://dx.doi.org/10.14334/jitv.v23i3.1855

Deficiencies or excess minerals such as $\mathrm{P}, \mathrm{Cu}$, and $\mathrm{Zn}$ are associated with subnormal fertility and anoestrus conditions in cows. This study was conducted in a veterinary unit in Menufiya, Egypt. Eighteen head of crossbred cows were randomly selected at random at estrus time (estrus group) and as a control 14 head of crossbred cows were selected from newly-calving dams at about 6-12 hours after calving (control group). The aim of this study was to use the components of biochemistry and progesterone hormone on estrus day of crossbreeding cattle in Egypt. The information from this study will be used to confirm estrus time to improve mating percentage. In blood plasma, the concentrations of all biochemical components and progesterone concentrations in estrus animals are higher than control cows except globulin. The results showed that blood plasma from control animal obtained Mg, Ca / P ratio, Co, Cu, Zn, Se, and Mo concentration is higher than estrus cattle. On the other hand, blood plasma concentrations of $\mathrm{Na}, \mathrm{K}, \mathrm{Ca}, \mathrm{P}, \mathrm{Mn}$, and $\mathrm{Fe}$ are higher in estrus cattle. The progesterone concentration of estrus cattle is lower during summer than in winter. In estrus cows, higher plasma macro-elements were found in winter than in summer except for $\mathrm{K}$, $\mathrm{Ca}$ and $\mathrm{Ca} / \mathrm{P}$ ratio. On the other side of estrus cattle, all trace elements of blood plasma are higher in winter than in summer except Zn, Mn, Se, and Fe.

Key Words: Cattle, Glucose, Cholesterol, Minerals, Progesterone

\section{INTRODUCTION}

Reproduction is one of the critical pillars of dairy production. Many dairy herds do not achieve their targets for reproductive performance and incur a substantial economic opportunity cost. Reproductive management has received increased attention in recent years as new technologies and programs have been developed to aid dairy managers in efficiently breeding cows and heifers (Widmar \& Wolf 2008). Despite the fact that postpartum uterine disease is only one component of reproductive performance, and that it generally has secondary importance to insemination efficiency (LeBlanc 2005), it has traditionally occupied a substantial amount of veterinarians' attention. Effective breeding management is a crucial tool to enhance the reproductive and productive performance of dairy cattle. Failure to detect and correctly interpret signs of estrus can contribute to a significant loss in the dairy industry (Barr 1975; Britt 1985). 
Visual heat detection programs were relatively more sensitive to labour costs than synchronization programs. In addition, past reproductive performance was found to affect the determination of which reproductive program was optimal. Farms that had attained high levels of labour efficiency for visual heat detection in the past had less incentive to adopt a synchronization program than farms with less efficient visual heat detection (Widmar \& Wolf 2008). Although, this visual observation of animals for signs of estrus is a standard method of estrus detection across the globe, in developed countries objective tests, are used to confirm estrus (Rao et al. 2013), including measuring serum/plasma or milk progesterone (P4) levels, and to successfully breed cattle (Mekonnin et al. 2017).

Minerals are the essential nutrients bearing a significant role in the animal reproduction because their excess or deficiency produces a detrimental effect on the performance of livestock. Trace elements including $\mathrm{Cu}, \mathrm{Co}, \mathrm{Zn}, \mathrm{Fe}, \mathrm{Se}, \mathrm{I}, \mathrm{Mo}, \mathrm{Mn}$ and certain macroelements like $\mathrm{K}, \mathrm{Ca}, \mathrm{Na}, \mathrm{Cl}$, P have been found to be essential for healthy livestock growth (Underwood 1981). Trace elements may function as cofactors, as activators of enzymes, or as stabilizers of secondary molecular structure (Valee \& Wacker 1976). Deficiency or excess of minerals like $\mathrm{P}, \mathrm{Cu}$ and $\mathrm{Zn}$ have been associated with subnormal fertility and anoestrus conditions (Moddie 1965). The aim of this study was to use the components of biochemistry and progesterone hormone on estrus day of crossbred cattle in Egypt. The information from this study will be used to confirm estrus time to improve mating percentage.

\section{MATERIALS AND METHODS}

The present study was carried out in veterinary units in Menufiya, Egypt during one year from May 2013 to April 2014. Eighteen head of crossbred of 4-9 years old cows that have 2-6 parity experience with 335 to $556 \mathrm{~kg}$ LBW were randomly selected at estrus time (estrus group) and as a control 14 head of crossbred cows were selected from newly-calving dams at about 6-12 hours after calving (control group). Cows were fed rations consisted of a commercial concentrate feed mixture (60\% yellow corn, $15 \%$ wheat bran, $23 \%$ soybean meal, $1 \%$ Na CL and 1\% mineral mixtures), Egyptian clover (Trifolium alexandrinum) and rice straw, while others were fed bran and green clover and rice straw. Animals were milked twice daily morning and evening milking. Blood samples were collected from the jugular vein of all cows. Blood samples were collected into clean heparinized test tubes and transported to the laboratory, centrifuged at $3000 \mathrm{rpm}$ for 20 minutes and blood plasma was carefully separated and stored frozen at $20^{\circ} \mathrm{C}$ until the time of chemical analyses. Blood plasma was carefully digested by adding $10 \mathrm{ml}$ concentrate
$\mathrm{H}_{2} \mathrm{SO}_{4}$ and two drops of $\mathrm{H}_{2} \mathrm{O}_{2}$ to $1 \mathrm{ml}$ of blood plasma and heated. The digested sample was diluted with distilled water at a ratio of 1:50. The concentration of macro- ( $\mathrm{Na}, \mathrm{K}, \mathrm{Mg}$, and $\mathrm{Ca}$ ) and micro- (Mn, Cd, Se, $\mathrm{Co}, \mathrm{Cu}, \mathrm{Mo}, \mathrm{Fe}$, and $\mathrm{Zn}$ ) elements were determined in blood plasma using an atomic absorption spectrophotometer (UNICAM 929 AA®). A standard ICP-OES (Perkin-Elmer, Optima 2000 DV ${ }^{\circledR}$ ) analyzer system was used for the determination according to (Oser 1965). Progesterone was estimated in both plasma and milk by the radioimmunoassay (RIA) technique using the coated tube kits according to Haynes et al. (1980) and Blight \& White (1983). The kit was purchased from Institute of Isotopes Co. LTD. Budapest and was labelled with I 125. The tubes were counted using computerized Gamma Counter (Packard Instrument Company $\left.{ }^{\circledR}\right)$. The standard curve of P4 ranged between 0.0 and $37.7 \mathrm{ng} / \mathrm{ml}$. All reagents were equilibrated to room temperature. Then duplicate tubes were labelled for each of total counts $(\mathrm{T})$, non-specific binding (NSB) zero standard (standard 1=B0), standards (S2-6), control (C) and either milk or plasma samples (S). The reagents and samples were mixed thoroughly before used, then $50 \mu \mathrm{l}$ from each of standards, control, and samples were inserting into the adequately labelled tubes. Thereafter $100 \mu \mathrm{l}$ of tracer solution and $100 \mu \mathrm{l}$ of antiserum were pipetted into all tubes except $\mathrm{T}$ and NSB, which were antiserum free. All tubes were vortex mixed thoroughly for $2-5$ seconds except $\mathrm{T}$. The tubes were incubated for 2 hours at room temperature $\left(20-28^{\circ} \mathrm{C}\right)$, and then they were placed on a separate tube rack. A bottle containing magnetic immunosorbent (MIS) was shacked and swirled gently until homogeneity then $500 \mu \mathrm{l}$ was added to each tube except $\mathrm{T}$. All tubes were vortex mixed thoroughly and incubated for 15 minutes at room temperature. The bound fraction was magnetically separated. The rack was attached to the magnetic separator base, and the MIS particles were settled for 5 minutes. The supernatant was poured off and discarded. The tubes were placed on a pad of absorbent tissue and allowed to drain for 2 minutes. The bound fraction was also separated by centrifugation for 15 minutes at $1500 \mathrm{xg}$. The radioactivity of all tubes was counted preferably not less than 60 seconds. Data obtained were statistically analyzed using the computer program of SAS (2004) (Descriptive statistics, ANOVA and Duncan test was used to determine the significant differences among means at $\alpha=0.05$ ).

\section{RESULTS AND DISCUSSION}

\section{Progesterone and biochemical components}

The concentration of blood biochemical components including cholesterol $(\mathrm{CH})$, glucose $(\mathrm{G})$, total protein 
Table 1. Concentrations of P4 and blood biochemical components in control and on the day of estrus in crossbred cattle

\begin{tabular}{|c|c|c|c|c|}
\hline Items & Case & Mean \pm SE & Min & Max \\
\hline Progesterone concentration & Control & $0.50 \pm 0.01^{\mathrm{a}}$ & 0.42 & 0.55 \\
\hline P4 (ng/ml) & Estrus & $0.58 \pm 0.01^{\mathrm{a}}$ & 0.50 & 0.66 \\
\hline \multicolumn{5}{|c|}{ Blood biochemical components: } \\
\hline \multirow[t]{2}{*}{ Cholesterol (mg/dl) } & Control & $74.74 \pm 0.71^{\mathrm{b}}$ & 72.59 & 78.65 \\
\hline & Estrus & $217.93 \pm 12.11^{\mathrm{a}}$ & 121.95 & 273.17 \\
\hline \multirow[t]{2}{*}{ Glucose (mg/dl) } & Control & $65.25 \pm 0.14^{\mathrm{a}}$ & 6.38 & 7.68 \\
\hline & Estrus & $58.78 \pm 3.1^{\mathrm{b}}$ & 33.93 & 71.43 \\
\hline \multirow[t]{2}{*}{ Total protein (mg/dl) } & Control & $6.08 \pm 0.09^{b}$ & 5.48 & 6.35 \\
\hline & Estrus & $6.77 \pm 0.25^{\mathrm{a}}$ & 4.86 & 8.00 \\
\hline \multirow[t]{2}{*}{ Albumin (mg/dl) } & Control & $1.17 \pm 0.05^{\mathrm{b}}$ & 0.90 & 1.33 \\
\hline & Estrus & $4.80 \pm 0.22^{\mathrm{a}}$ & 3.07 & 6.46 \\
\hline \multirow[t]{2}{*}{ Globulin (mg/dl) } & Control & $5.29 \pm 0.19^{\mathrm{a}}$ & 4.71 & 6.61 \\
\hline & Estrus & $1.97 \pm 0.15^{\mathrm{b}}$ & 0.47 & 3.13 \\
\hline \multirow[t]{2}{*}{ A/G Ratio } & Control & $0.22 \pm 0.58^{\mathrm{b}}$ & 0.12 & 1.49 \\
\hline & Estrus & $2.43 \pm 0.05^{\mathrm{a}}$ & 1.09 & 2.02 \\
\hline
\end{tabular}

Control ( $\mathrm{n}=14)$, Estrus $(\mathrm{n}=18)$

Significant different $(\mathrm{P}<0.05)$ marked by different superscript letter in the same row for each blood biochemical component

(TP), albumin $(\mathrm{AL})$, globulin $(\mathrm{GL}), \mathrm{AL} / \mathrm{GL}$ ratio and progesterone concentration (P4) and those at time of estrus are depicted in the Table (1). Results show that concentrations of all blood biochemical components and (P4) concentrations at estrus were higher than control cows except (GL).

In the control cows that the animal is just calving the level of P4 was not significantly different than in the estrus cows. It is often assumed that a larger corpus luteum will produce more progesterone and generate higher circulating plasma concentrations. Corpus luteum weight and plasma progesterone concentration increased between day 5 and day 8 of the estrus cycle. During the early stage of corpus luteum development, a relationship between size and progesterone is present, by day 8 of the cycle, the size of the corpus luteum is no longer of importance in determining circulating progesterone concentrations (Mann 2009).

Díaz et al. (1988) reported that the P4 profiles showed no differences among groups. In Holstein P4 levels ranged from $0.5 \mathrm{ng} / \mathrm{ml}$ plasma on the day of estrus (Day 0) to $5.1 \mathrm{ng} / \mathrm{ml}$ at the luteal phase peak (Day 13). In Brahman, P4 levels ranged from $0.5 \mathrm{ng} / \mathrm{ml}$ on Day 0 to $9.2 \mathrm{ng} / \mathrm{ml}$ on Day 13. In Carora-type and crossbred females, P4 levels ranged from $0.5 \mathrm{ng} / \mathrm{ml}$, on Day 0 , to $13.7 \mathrm{ng} / \mathrm{ml}$ on Day 12 and $8.8 \mathrm{ng} / \mathrm{ml}$ on Day 13.

On the other hand, Mondal \& Prakash (2003) reported that in Sahiwal cows with overt estrus, plasma progesterone concentrations during periestrus, early luteal, mid-luteal and late luteal phase were $0.40 \pm 0.02$, $0.74 \pm 0.10$, $1.94 \pm 0.22$, and $0.63 \pm 0.16 \mathrm{ng} / \mathrm{ml}$, respectively and the corresponding values in cows with silent estrus being $0.47 \pm 0.03,0.94 \pm 0.08,1.39 \pm 0.13$, and $0.95 \pm 0.19 \mathrm{ng} / \mathrm{ml}$, respectively. The overall plasma progesterone levels in cows that exhibited overt estrus were $1.23 \pm 0.99 \mathrm{ng} / \mathrm{ml}$ as against $1.08 \pm 0.09 \mathrm{ng} / \mathrm{ml}$ in silent estrus. It was concluded that progesterone levels were lower $(\mathrm{P}>0.05)$ in cows that exhibited silent estrus compared to overt estrus.

Blood glucose appears to be one of the key nutrients affecting cyclicity in farm animals, and a minimum level of $60-40 \mathrm{mg} / \mathrm{ml}$ is required to maintain the physiological processes of the body (Duke 1970). According to Dowine \& Gelman (1976), low blood glucose may be associated with infertility. Dutta et al. (1988) reported significantly lower serum glucose level in anoestrus than normally cycling animals. El-Azab et al. (1993) reported significantly higher serum protein in cyclic cows than the noncycling ones. However, Tegegne et al. (1993) found an inconsistent trend. Qureshi (1998) reported higher blood urea level in anoestrus animals than those resuming cyclicity within 45 days postpartum. Burle et al. (1995) reported the lowest serum concentration of cholesterol in anoestrus than in cycling cows. Significantly variable reports were available on the level of these biochemical constituents. Lyubestsky (1997) reported higher values 
of total serum protein in endometriotic buffaloes and cows compared to cyclic buffaloes and cows, respectively. However, Burle et al. (1995) reported the significantly higher value of total serum protein in cyclic cows.

Plasma glucose concentration was significantly $(\mathrm{P}<0.01)$ higher in estrus animals that in anoestrus animals, Singh \& Singh (2006). In the anoestrus group of animals, the mean value of cholesterol was insignificantly higher than the mean value in estrus animals. The mean values of the total serum protein of crossbred heifers for the estrus group as well as the anoestrus group were found in the normal range. An optimum level of total protein in blood serum is essential for the expression of estrus sign in cows. Deficiency of protein intake in cows can cause infertility, and altered hormonal balance caused by elevated blood urea nitrogen levels also may decrease fertility and reproductive (Amin 2014).

Optimum concentrations of blood glucose and proteins induce estrus cyclicity via hypothalamohypophyseal system (Tandle et al. 1998). Detrimental effects of protein metabolites (blood urea nitrogen) may occur not only at different stages of oocyte development but also during fertilization and blastocyst formation (Jorritsma et al. 2003). High plasma glucose and proteins were recently reported in cycling dairy cattle compared to non-cycling (Kumar et al. 2010).

Saied (2017) reported that the means of total protein was $6.5 \pm 1.2 \mathrm{~g} / \mathrm{dL}$ in crossbred cattle in Egypt. Dezfouli et al. (2013) reported that the means of total protein and glucose were $7.38 \pm 0.39 \mathrm{~g} / \mathrm{dL}$ and $6.17 \pm 0.40 \mathrm{mg} / \mathrm{dL}$, respectively in Holstein dairy cows and crossbreeds in the Tehran.

\section{Macro-and micro-elements}

The concentration of blood macro- and microelements in plasma of control cows and those with reproductive disorders are shown in the Table $(2,3)$. In control cows: $\mathrm{Mg}, \mathrm{Ca} / \mathrm{P}$ ratio, $\mathrm{Co}, \mathrm{Cu}, \mathrm{Zn}, \mathrm{Se}$, and $\mathrm{Mo}$ were higher than in the estrus cows. On the other hand, the blood concentrations of $\mathrm{Na}, \mathrm{K}, \mathrm{Ca}, \mathrm{P}, \mathrm{Mn}$, and Fe was higher in estrus than in control cows.

Meanwhile, Small et al. (1997) reported that serum $\mathrm{Ca}, \mathrm{Na}, \mathrm{S}, \mathrm{Cu}, \mathrm{Fe}, \mathrm{Zn}$, and $\mathrm{Mn}$ did not differ $(\mathrm{P}>0.05)$ between first service conception groups, but sodium $(\mathrm{Na})$ and copper $(\mathrm{Cu})$ were higher $(\mathrm{P}<0.05)$ at estrus than at day 21, especially in nulliparous heifers. Concentrations of serum magnesium $(\mathrm{Mg})$ were low $(<0.74 \mathrm{mmol} / \mathrm{L})$ and potassium $(\mathrm{K})$ high $(>4.5 \mathrm{mmol} / \mathrm{L})$ in heifers and cows but in nulliparous heifers only, serum magnesium $(\mathrm{Mg})$ and potassium $(\mathrm{K})$ were lowest $(\mathrm{P}<0.05)$ at estrus for those that conceived. Serum boron (B) concentrations were generally higher $(\mathrm{P}<0.05)$ in animals that conceived especially on day 21 when boron $(\mathrm{B})$ concentrations were higher $(\mathrm{P}<0.05)$ than at estrus. Serum phosphorus (P) concentrations were high $(>3.5 \mathrm{mmol} / \mathrm{L})$, but highest in animals that conceived especially on day 21 . It is concluded that phosphorus (P) and boron (B) may be dietary factors limiting first service conception in beef cows fed conserved forage.

Macro-elements such as $\mathrm{Ca}, \mathrm{P}, \mathrm{Na}, \mathrm{Mg}, \mathrm{K}, \mathrm{S}$, and Microelements such as $\mathrm{Cu}, \mathrm{Fe}, \mathrm{Zn}, \mathrm{Mn}$, and Se are essential nutrients that function in the regulation of cellular metabolism and when deficient in ruminant diets have caused reproductive problems (Hidiroglou 1979; ARC 1980; Underwood 1981).

Saied (2017) reported that the means of $\mathrm{Na}, \mathrm{K}, \mathrm{Ca}$, and $\mathrm{P}$ were $140.04 \pm 0.85 \mathrm{mEq} / \mathrm{l}, 5.20 \pm 0.22 \mathrm{mEq} / \mathrm{l}$, $9.11 \pm 0.2 \mathrm{mg} / \mathrm{dl}$, and $3.39 \pm 0.20 \mathrm{mEq} / \mathrm{l}$, respectively in crossbred cattle in Egypt. Dezfouli et al. (2013) reported that the means of $\mathrm{Na}, \mathrm{K}, \mathrm{Mg}, \mathrm{Ca}$, and $\mathrm{P}$ were $140.600 \pm 3.050 \mathrm{mmol} / \mathrm{L}, \quad 4.340 \pm 0.321 \mathrm{mmol} / \mathrm{L}$, $1.99 \pm 0.19 \mathrm{mg} / \mathrm{dL}, 9.76 \pm 0.76 \mathrm{mmol} / \mathrm{L}$, and $6.17 \pm 0.40$ $\mathrm{mg} / \mathrm{dL}$, respectively in Holstein dairy cows and crossbreeds in the Tehran.

Table 2. Blood macro elements in normal and on the day of estrus in crossbred cattle

\begin{tabular}{lcccccccc}
\hline Case & Macro & $\begin{array}{c}\text { Mean } \pm \text { SE } \\
(\mathrm{mg} / \mathrm{dl})\end{array}$ & Min & Max & Macro & $\begin{array}{c}\text { Mean } \pm \text { SE } \\
(\mathrm{mg} / \mathrm{dl})\end{array}$ & Min & Max \\
\hline Control & $\mathrm{Na}$ & $142.13 \pm 0.25^{\mathrm{b}}$ & 139.32 & 144.93 & $\mathrm{Ca}$ & $5.46 \pm 0.16^{\mathrm{b}}$ & 6.16 & 16.80 \\
Estrus & & $164.95 \pm 7.04^{\mathrm{a}}$ & 101.1 & 208.3 & & $13.65 \pm 0.54^{\mathrm{a}}$ & 4.60 & 6.40 \\
Control & $\mathrm{K}$ & $4.21 \pm 0.10^{\mathrm{b}}$ & 3.68 & 4.72 & & $1.92 \pm 0.04^{\mathrm{b}}$ & 1.61 & 2.00 \\
Estrus & & $24.66 \pm 1.46^{\mathrm{a}}$ & 6.35 & 35.28 & $\mathrm{P}$ & $5.57 \pm 0.30^{\mathrm{a}}$ & 3.18 & 7.90 \\
Control & \multirow{2}{*}{ Mg } & $4.46 \pm 0.07^{\mathrm{a}}$ & 3.89 & 4.65 & $\mathrm{Ca} / \mathrm{P}$ & $2.87 \pm 0.14^{\mathrm{a}}$ & 2.32 & 3.78 \\
Estrus & & $2.86 \pm 0.19^{\mathrm{b}}$ & 1.63 & 4.51 & Ratio & $2.53 \pm 0.14^{\mathrm{b}}$ & 1.74 & 3.82 \\
\hline
\end{tabular}

Control ( $\mathrm{n}=14)$, Estrus ( $\mathrm{n}=18)$

Significant different $(\mathrm{P}<0.05)$ marked by different superscript letter in the same row for each macro-elements 
Table 3. Blood micro-elements in control and on the day of estrus in crossbred cattle

\begin{tabular}{|c|c|c|c|c|c|c|c|c|}
\hline Case & Micro & $\begin{array}{c}\text { Mean } \pm \text { SE } \\
(\mu \mathrm{g} / \mathrm{dl})\end{array}$ & Min & Max & Micro & $\begin{array}{c}\text { Mean } \pm \text { SE } \\
(\mu \mathrm{g} / \mathrm{dl})\end{array}$ & Min & Max \\
\hline Control & \multirow{2}{*}{$\mathrm{CO}$} & $0.89 \pm 0.11^{\mathrm{b}}$ & 0.49 & 1.54 & \multirow{2}{*}{ Se } & $10.46 \pm 0.24^{\mathrm{a}}$ & 9.14 & 12.02 \\
\hline Estrus & & $3.18 \pm 0.28^{\mathrm{a}}$ & 1.30 & 4.61 & & $0.44 \pm 0.03^{\mathrm{b}}$ & 0.22 & 0.59 \\
\hline Control & \multirow{2}{*}{$\mathrm{CU}$} & $1.26 \pm 0.14$ & 0.66 & 1.84 & \multirow{2}{*}{$\mathrm{Fe}$} & $0.35 \pm 0.02^{\mathrm{b}}$ & 0.20 & 0.45 \\
\hline Estrus & & $1.04 \pm 0.16$ & 0.09 & 2.02 & & $3.42 \pm 0.57^{\mathrm{a}}$ & 1.10 & 7.77 \\
\hline Control & \multirow{2}{*}{$\mathrm{Zn}$} & $5.46 \pm 0.09^{\mathrm{a}}$ & 4.91 & 5.72 & \multirow{2}{*}{ Mo } & $0.59 \pm 0.01^{\mathrm{a}}$ & 0.58 & 0.66 \\
\hline Estrus & & $0.74 \pm 0.07^{\mathrm{b}}$ & 0.20 & 1.08 & & $0.04 \pm 0.002^{\mathrm{b}}$ & 0.02 & 0.05 \\
\hline Control & \multirow{2}{*}{ Mn } & $0.82 \pm 0.047^{\mathrm{a}}$ & 0.65 & 1.13 & \multirow{2}{*}{$\mathrm{Cd}$} & $0.14 \pm 0.002^{b}$ & 0.13 & 0.15 \\
\hline Estrus & & $0.89 \pm 0.37^{\mathrm{a}}$ & 0.04 & 6.70 & & $0.75 \pm 0.08^{\mathrm{a}}$ & 0.19 & 1.44 \\
\hline
\end{tabular}

Control ( $n=14)$, Estrus $(n=18)$

Significant different $(\mathrm{P}<0.05)$ marked by different superscript letter in the same row for each micro-elements

Concentrations of minerals in blood serum or plasma are generally related to intake but are influenced by sex, breed, age, and reproductive status, e.g., pregnancy or lactation (ARC 1980; Underwood 1981). Differences in serum mineral concentrations between first service conception groups at estrus/first service may have been indicative of an influence on ovulation and subsequent development of the corpus luteum. Plasma levels of $\mathrm{P}$ as low as $1.56 \mathrm{mmol} \mathrm{L}-1$ have not affected fertility in dairy cows (Brodison et al. 1989).

Concentrations of $\mathrm{K}$ in forage were above the NRC (NRC 1984) since blood $K$ has been shown to be related to dietary K (Fisher et al. 1994). Serum Ca concentrations were normal and did not differ between first service conception groups. Dietary concentrations of $\mathrm{Ca}$ were higher than NRC (NRC 1984) recommended minimum allowances for heifers and cows. However, the rise in serum Estradiol at estrus would have stimulated an increase in serum Ca (Horst 1984). A deficiency of Mg was not expected, yet serum $\mathrm{Mg}$ was $<0.745 \mathrm{mmol} / \mathrm{L}$ which has defined hypomagnesia in cattle (ARC 1980). Others have shown that supplemental $\mathrm{Cu}$ and $\mathrm{Mg}$ improved fertility in dairy cows even though plasma concentrations of $\mathrm{Cu}$ and $\mathrm{Mg}$ were similar among supplemented and unsupplemented groups (Ingraham et al. 1987).

Serum $\mathrm{Na}$ was higher at estrus than on day 21, especially in nulliparous heifers and cows. In nulliparous heifers, serum S was also higher at estrus than on day 21 especially in animal (Small et al. 1997). Similarly serum $\mathrm{Fe}, \mathrm{Zn}$ and $\mathrm{Mn}$ concentrations were Control (Puls 1981) and did not differ among the first service groups. Barui et al. (2015) reported among the minerals; zinc was found to play the most vital role to cause repeat breeding condition in the farm animals. A significant difference in the levels of calcium, phosphorus, magnesium, and iron was observed in the case of serum minerals. Mean phosphorus level in the anoestrus animals was lower than the suggested critical level of $4.5 \mathrm{~g} / 100 \mathrm{ml}$ (Kunj et al. 2006). Saied (2017) reported that the means of $\mathrm{Cu}$ and $\mathrm{Fe}$ were $10.39 \pm 0.36$ and $140.5 \pm 0.15 \mathrm{mEq} / \mathrm{l}$, respectively in crossbred cattle in Egypt.

\section{Effect of the season on blood biochemistry}

The effect of season on the concentration of blood biochemical components at estrus time is depicted in the Table (4). This study represents that progesterone concentrations tended to be higher on day of estrus in winter than in summer but not significantly different and these results disagree with Rao et al. (1982) who reported that progesterone concentrations on the day of estrus and also in the luteal phase of the cycle were significantly higher $(\mathrm{P} \leq 0.01)$ in the colder seasons than in the hot and dry and hot and humid seasons. Meanwhile, Roussel et al. (1977) found a significantly higher level of progesterone in monthly samples for cows in the hot season. Also, all blood biochemical components were higher on the day of estrus in winter than in summer.

Cholesterol concentration in estrus cows was higher in winter than in summer. In line, the result was reported in Nguni cattle resulted. It was concluded that Nguni cattle had lower cholesterol in the hot-wet season than crossbreds and energy deficits mostly occurred during the late cool-dry season on the sweet rangeland (Mapiye et al. 2010). Glucose concentration in estrus cows was higher in winter than in summer. The decrease in plasma glucose and plasma cholesterol during the hotter period was reported Abeni et al. (2007). 
Table 4. Seasonal variations of blood biochemical components in control and on the day of estrus in crossbred cattle

\begin{tabular}{lcccc}
\hline \hline \multirow{2}{*}{ Items } & \multicolumn{2}{c}{ Control } & \multicolumn{2}{c}{ Estrus } \\
\cline { 2 - 5 } & Summer & Winter & Summer & Winter \\
\hline P4 conc.(ng/ml) & $0.49 \pm 0.01^{\mathrm{a}}$ & $0.50 \pm 0.01^{\mathrm{a}}$ & $0.54 \pm 0.02^{\mathrm{a}}$ & $0.59 \pm 0.01^{\mathrm{a}}$ \\
Cholesterol $_{(\mathrm{mg} / \mathrm{dl})}$ & $74.62 \pm 2.02^{\mathrm{a}}$ & $74.78 \pm 0.78^{\mathrm{a}}$ & $168.97 \pm 16.86^{\mathrm{b}}$ & $231.92 \pm 12.65^{\mathrm{a}}$ \\
Glucose $_{(\mathrm{mg} / \mathrm{dl})}$ & $7.59 \pm 0.09^{\mathrm{a}}$ & $7.15 \pm 0.16^{\mathrm{a}}$ & $38.91 \pm 4.89^{\mathrm{b}}$ & $64.46 \pm 2.09^{\mathrm{a}}$ \\
Total protein $_{(\mathrm{g} / \mathrm{dl})}$ & $6.27 \pm 0.08^{\mathrm{a}}$ & $6.02 \pm 0.12^{\mathrm{a}}$ & $5.51 \pm 0.55^{\mathrm{b}}$ & $7.13 \pm 0.19^{\mathrm{a}}$ \\
Albumin $_{(\mathrm{g} / \mathrm{dl})}$ & $1.32 \pm 0.01^{\mathrm{a}}$ & $1.13 \pm 0.06^{\mathrm{a}}$ & $3.86 \pm 0.36^{\mathrm{b}}$ & $5.07 \pm 0.22^{\mathrm{a}}$ \\
Globulin $_{(\mathrm{g} / \mathrm{dl})}$ & $4.75 \pm 0.02^{\mathrm{a}}$ & $5.44 \pm 0.23^{\mathrm{b}}$ & $1.65 \pm 0.20^{\mathrm{b}}$ & $2.06 \pm 0.19^{\mathrm{a}}$ \\
Alb/Glob Ratio & $148.75 \pm 0.40^{\mathrm{a}}$ & $146.65 \pm 0.67^{\mathrm{a}}$ & $1.43 \pm 0.02^{\mathrm{a}}$ & $1.43 \pm 0.06^{\mathrm{a}}$ \\
\hline
\end{tabular}

Control ( $n=14)$, Estrus $(n=18)$

Significant different $(\mathrm{P}<0.05)$ marked by different superscript letter in the same row between each group within the same blood biochemical component

\section{Effect of season on macro- and micro-elements}

The effect of season on macro- and micro-elements at estrus time is depicted in the Tables $(5,6)$. This study represents that in hot and cold season, $\mathrm{Na}, \mathrm{K}, \mathrm{Ca}$, and $\mathrm{P}$ were higher on the day of estrus than Control cattle. On the other hand, $\mathrm{Mg}$ and $\mathrm{Ca} / \mathrm{P}$ Ratio were lower on the day of estrus than Control cattle. Pearson et al. (1964) could not demonstrate a change in plasma Ca values of five mature cows when Ca estimations were performed daily during four estrus periods. Other workers, Bacih et al. (1969) reported that the total serum Ca of a Shorthorn cow, but not of a Jersey, fell about $2 \mathrm{mg}$ per $100 \mathrm{ml}$ at the time of estrus.

Minerals are involved in all living processes, either in the capacity of structural elements or as regulators of almost all metabolic processes (Bauman \& Currie 1980). Apart from the above-indicated roles, minerals are essential for milk production of high-yielding cows. Consequently, their role assumes increasing importance. Homeostasis of calcium, phosphorus, and magnesium is primarily affected by the very same homeostatic mechanisms, and as a result, the changes in their concentrations are in most cases mutually linked. Calcium is the most pervasive mineral in an organism. The maintenance need of calcium is approximately 15.4 $\mathrm{mg} \mathrm{Ca} / \mathrm{kg}$ of body mass (Hansard et al. 1954). The need for lactation is approximately $1.23 \mathrm{~g} \mathrm{Ca} / \mathrm{kg}$ of the produced milk. Calcium absorption depends on its intake, and it is reduced when the animal takes more calcium in its food than it is needed.

The research about calcium level in dependence on the physiological condition and seasonal variations did not show the influence of the above-indicated factors on calcium values in cows (Yokus et al. 2006). However, Krnić et al. (2003) reported not only considerably lower calcium values in cows 1-5 days from calving but also hypocalcemia in lactating cows and in cows 5-10 days before calving. Lower bottom values of calcium are also reported by Olayemi et al. (2001). They found that $39 \%$ of cows had the calcium concentration $<2$ $\mathrm{mmol} / \mathrm{L}$. The values of magnesium concentration in the literature vary widely such as $0.7-1.2 \mathrm{mmol} / \mathrm{L}$ (Merck 2003), 0.74-0.95 mmol/L (Kaneko et al. 2008; Radostits et al. 2000).

Nejra \& Josip (2012) indicated a greater need of cows for phosphorus than that provided by plants contained in the animal diet, and this is a direct consequence of low values of this mineral in the soil composition. The age of animals also influences the value of phosphorus concentration. In other words, the phosphorus level increases with the age of animals (Roussel et al. 1982). Moreover, this study represents that in the hot season, Co, Mn, Fe, and Cd were higher on the day of estrus than Control cattle. On the other hand, $\mathrm{Cu}, \mathrm{Zn}$, Se, and Mo were lower on the day of estrus than Control cattle. Nejra \& Josip (2012) have proved the influence of sampling season on the value of calcium concentration in lactating cows and those in dry period (Figure 1). In cows up to fifteen days from calving, the influence of sampling season on the value of calcium has not been proved. The calcium level depends on the feed so that the different botanical make-up of pastures, and grazing in general, may be a cause of significant differences established during various seasons of sample taking. Certain values of calcium concentration have shown significant differences depending on the reproductive cycle of cows. The highest value of calcium concentration has been established in cows in the dry period with samples taken in summer while lactating and postparturient cows have significantly lower values of calcium concentration in the same period. The mean calcium 
Table 5. Seasonal variations of plasma macro elements on the day of estrus in crossbred cattle

\begin{tabular}{lcccc}
\hline \hline \multirow{2}{\text{Items}}{$(\mathrm{mg} / \mathrm{dl})$} & \multicolumn{2}{c}{ Control } & \multicolumn{2}{c}{ Estrus } \\
\cline { 2 - 5 } $\mathrm{Na}$ & Summer & Winter & $128.05 \pm 15.13^{\mathrm{b}}$ & Winter \\
$\mathrm{K}$ & $6.19 \pm 0.16^{\mathrm{a}}$ & $6.24 \pm 0.19^{\mathrm{a}}$ & $27.29 \pm 2.23^{\mathrm{a}}$ & $23.91 \pm 1.75^{\mathrm{b}}$ \\
$\mathrm{Mg}$ & $4.15 \pm 0.16^{\mathrm{a}}$ & $4.23 \pm 0.13^{\mathrm{a}}$ & $2.17 \pm 0.36^{\mathrm{b}}$ & $3.06 \pm 0.19^{\mathrm{a}}$ \\
$\mathrm{Ca}$ & $4.60 \pm 0.02^{\mathrm{a}}$ & $4.42 \pm 0.08^{\mathrm{a}}$ & $14.89 \pm 1.15^{\mathrm{a}}$ & $13.29 \pm 0.59^{\mathrm{b}}$ \\
$\mathrm{P}$ & $5.47 \pm 0.32^{\mathrm{a}}$ & $5.46 \pm 0.19^{\mathrm{a}}$ & $5.48 \pm 0.24^{\mathrm{a}}$ & $5.60 \pm 0.39^{\mathrm{a}}$ \\
$\mathrm{Ca} / \mathrm{P}$ Ratio & $1.87 \pm 0.13^{\mathrm{a}}$ & $1.94 \pm 0.04^{\mathrm{a}}$ & $2.71 \pm 0.10^{\mathrm{a}}$ & $2.49 \pm 0.18^{\mathrm{b}}$ \\
\hline
\end{tabular}

Control $(\mathrm{N}=14)$, Estrus $(\mathrm{N}=18)$

Significant different $(\mathrm{P}<0.05)$ marked by different superscript letter in the same row between each treatment within the same Macro element

Table 6. Seasonal variations of microplasma elements on the day of estrus in crossbred cattle

\begin{tabular}{|c|c|c|c|c|}
\hline \multirow{2}{*}{$\begin{array}{l}\text { Items } \\
(\mu \mathrm{g} / \mathrm{dl})\end{array}$} & \multicolumn{2}{|c|}{ Control } & \multicolumn{2}{|c|}{ Estrus } \\
\hline & Summer & Winter & Summer & Winter \\
\hline Co & $0.84 \pm 0.35^{\mathrm{b}}$ & $0.91 \pm 0.11^{\mathrm{a}}$ & $1.97 \pm 0.24^{\mathrm{b}}$ & $3.53 \pm 0.30^{\mathrm{a}}$ \\
\hline $\mathrm{Cu}$ & $1.57 \pm 0.27^{\mathrm{a}}$ & $1.18 \pm 0.16^{\mathrm{b}}$ & $0.69 \pm 0.12^{\mathrm{b}}$ & $1.14 \pm 0.19^{\mathrm{a}}$ \\
\hline $\mathrm{Zn}$ & $5.67 \pm 0.02^{\mathrm{a}}$ & $5.40 \pm 0.11^{\mathrm{b}}$ & $1.70 \pm 0.17^{\mathrm{a}}$ & $0.74 \pm 0.07^{\mathrm{b}}$ \\
\hline $\mathrm{Mn}$ & $0.72 \pm 0.07^{\mathrm{b}}$ & $0.85 \pm 0.06^{\mathrm{a}}$ & $1.29 \pm 0.45^{\mathrm{a}}$ & $0.78 \pm 0.46^{\mathrm{b}}$ \\
\hline Se & $10.14 \pm 0.15^{\mathrm{a}}$ & $10.54 \pm 0.31^{\mathrm{a}}$ & $0.29 \pm 0.05^{\mathrm{a}}$ & $0.49 \pm 0.03^{b}$ \\
\hline $\mathrm{Fe}$ & $0.35 \pm 0.01^{\mathrm{a}}$ & $0.35 \pm 0.02^{\mathrm{a}}$ & $6.35 \pm 0.94^{\mathrm{a}}$ & $2.59 \pm 0.49^{b}$ \\
\hline Mo & $0.61 \pm 0.03^{\mathrm{a}}$ & $0.59 \pm 0.01^{\mathrm{a}}$ & $0.03 \pm 0.002^{\mathrm{a}}$ & $0.04 \pm 0.002^{\mathrm{a}}$ \\
\hline Cd & $0.13 \pm 0.001^{\mathrm{a}}$ & $0.14 \pm 0.003^{\mathrm{a}}$ & $0.38 \pm 0.04^{b}$ & $0.86 \pm 0.09^{\mathrm{a}}$ \\
\hline
\end{tabular}

Control ( $\mathrm{N}=14)$, Estrus $(\mathrm{N}=18)$

Significant different $(\mathrm{P}<0.05)$ marked by different superscript letter in the same row between each treatment within the same Microplasma element

level determined during summer in cows in the dry period was found to be higher $(3.1 \pm 0.16 \mathrm{mmol} / \mathrm{L})$ than those of the other published research findings (Kaneko et al. 2008; Merck 2003).

In this respect, all plasma macro elements were higher on the day of estrus in winter than in summer except $\mathrm{K}, \mathrm{Ca}$ and $\mathrm{Ca} / \mathrm{P}$ ratio. On the other hand, all plasma macro elements were higher on the day of estrus in winter than in summer except $\mathrm{Zn}, \mathrm{Mn}$, Se, and Fe. During the summer period, significantly lower levels of calcium were determined in cows immediately after calving. In interpreting the calcium level, we should not neglect the physiological hypocalcemia which occurs after calving, especially in dairy cows. If we make a comparison with the established reference values, we can notice hypocalcemia in many periparturient cows. However, these values are appropriate for the postpartum physiological condition (Oltner \& Bergland 1983).

\section{CONCLUSION}

Mineral concentrations from plasma blood sample of estrus crossbred cattle were lower than control cows. The concentrations of all blood biochemical components in the estrus cows were higher than that of control cows except for P4 and globulin concentration. Control animal contained higher $\mathrm{Mg}, \mathrm{Ca} / \mathrm{P}$ ratio, Co, $\mathrm{Cu}, \mathrm{Zn}$, Se, and Mo than that of estrus cattle. On the other hand, control cows have lower $\mathrm{Na}, \mathrm{K}, \mathrm{Ca}, \mathrm{P}, \mathrm{Mn}$, and $\mathrm{Fe}$ than estrus cows. Season affected macroelements of estrus cows. In estrus cows, higher plasma macro-elements were found in winter than in summer except for $\mathrm{K}, \mathrm{Ca}$, and $\mathrm{Ca} / \mathrm{P}$ ratio. On the other side of estrus cattle, all trace elements of blood plasma are higher in winter than in the summer except $\mathrm{Zn}, \mathrm{Mn}$, Se, and Fe. 


\section{REFERENCES}

Amin R. 2014, Nutrition: Its role in reproductive functioning of cattle-a review. Vet Clin Sci. 2:1-9.

Abeni F, Calamari L, Stefanini L. 2007. Metabolic conditions of lactating Friesian cows during the hot season in the Po valley. 1. Blood indicators of heat stress. Int J Biometeorol. 52:87-96.

[ARC] Agricultural Research Council. 1980. The nutrient requirements of ruminant livestock. Bureaux, Slough, (UK): Agricultural Research Council, Commonwealth Agricultural.

Bacih SJ, Messervy A. 1969. Observations on the diffusible calcium fraction in the serum of the cow during oestrus and during parturition. Vet Rec. 84:210-219.

Barr HL. 1975. Influence of estrus detection on days open in dairy herds. J Dairy Sci. 58:246-247.

Barui A, Batabyal S, Ghosh S, Saha D, Chattopadhyay S. 2015. Plasma mineral profiles and hormonal activities of normal cycling and repeat breeding crossbred cows: A comparative study. Vet World. 8:42-45.

Bauman DE, Currie WB. 1980. Partitioning of nutrients during pregnancy and lactation: A review of mechanisms involving homeostasis and homeorhesis. J Dairy Sci. 63:1514-1529.

Blight L, White G. 1983. I125- Labeled radioimmunoassay kits for progesterone evaluated for use in an in-vitro fertilization program. Clin Chem. 29:1024-1027.

Britt JH. 1985. Enhanced reproduction and its economic implications. J Dairy Sci. 68:1585-1592.

Brodison JA, Goodall EA, Armstrong JD, Givens DI, Gordon FJ, McCaughey WJ, Todd JR. 1989. Influence of dietary phosphorus on the performance of lactating dairy cattle. J Agric Sci. 112:303-311.

Burle PM, Mangle NS, Kothekhar MD, Kalorey DR. 1995. Blood biochemical profiles during various reproductive states of Sahiwal and Jersey X Sahiwal cattle. Livest Adv. 20:13-20.

Dezfouli MM, Eftekhari Z, Sadeghian S, Bahounar A, Jeloudari M. 2013. Evaluation of haematological and biochemical profiles in dairy cows with left displacement of the abomasums. Comp Clin Pathol. 22:175-179.

Díaz T, Manzo M, Trocóniz J, Benacchio N, Verde O. 1988. Plasma progesterone levels during the oestrous cycle of Holstein and Brahman cows, Carora type and cross-bred heifers. Theriogenology. 26:419-432.

Dowine JG, Gelman AL. 1976. The relationship between changes in body weight, plasma glucose and fertility in beef cows. Vet Rec. 11:210-212.

Duke HH. 1970. Physiology of domestic animals. 8th ed. Ithaca \& London (UK): Comstock Publishing Associates.
Dutta JC, Baruah RN, Dutta L, Talukdar SC. 1988. Blood biochemical studies in anoestrous and normal cyclic cattle. Indian Vet J. 65:239-241.

El-Azab MA, Badr A, El-Sadawy Shawki G, Borkat TM. 1993. Some biochemical changes in relation to postpartum ovarian activity in dairy cows. Indian $\mathrm{J}$ Anim Sci. 63:1244-1247.

Fisher LJ, Dinn N, Tait RM, Shelford JA. 1994. Effect of dietary potassium on the absorption and excretion of calcium and magnesium by lactating cows. Can J Anim Sci. 74:503-509.

Hansard SL, Comar CL, Plumlee MP. 1954. The effect of age upon calcium utilization and maintenance requirements in the bovine. J Anim Sci. 13:25-36.

Haynes S, Corcoran J, Eastman C, Doy F. 1980. Radioimmunoassay of progesterone in unextracted serum. Clin Chem. 26:1607-1609.

Hidiroglou M. 1979. Trace element deficiencies and fertility in ruminants. A review. J Dairy Sci. 62:1195-1206.

Horst R. 1984. Regulation of calcium and phosphorus homeostasis in the dairy cow. J Dairy Sci. 69:604-616.

Ingraham RH, Kappel LC, Morgan EB, Srikandakumar A. 1987. Correction of subnormal fertility with copper and magnesium supplementation. J Dairy Sci. 70:167-180.

Jorritsma R, Wensing T, Kruip T, Vosa P, Noordhuizen J. 2003. Metabolic changes in early lactation and impaired reproductive performance in dairy cows. Vet Res. 34:11-26

Kaneko JJ, Harvey JW, Bruss ML. 2008, Clinical biochemistry of domestic animals. 6th ed. New York (USA): Academic Press. p. 64.

Krnic J, Podžo M, Hodžic A, Hamamdžic M, Pašic-Juhas E, Mihaljevic M. 2003. Metabolicki profil krava u laktaciji i peripartalno. Veterinaria. 52:75-86.

Kumar S, Saxena A, Ramsagar. 2010. Comparative studies on metabolic profile of anestrous and normal cyclic murrah buffaloes. Buffalo Bull. 29:7-11.

Kunj V, Singh AP. 2006. Blood biochemical constituents in subestrus cows. Indian Vet J. 83:459-460.

LeBlanc S. 2005. Overall reproductive performance of Canadian dairy cows: challenges we are facing. Adv Dairy Tech. 17:137-157.

Lyubestsky VI. 1997. Plasma protein fractions in cows with post parturient endometritis. Visnik-Agrarnoi-Nauli. 6:28-33.

Mann GE. 2009. Corpus luteum size and plasma progesterone concentration in cows. Anim Reprod Sci. 115:296-299.

Mekonnin AB, Howie AF, Riley SC, Gidey G, Tegegne DT, Desta G, Ashebir G, Gebrekidan B, Harlow CR. 2017. Serum, milk, saliva, and urine progesterone and estradiol profiles in crossbred (Zebu $x$ Holstein Friesian) dairy cattle. Anim Husb Dairy Vet Sci. 1:1-10. 
Merck. 2003. Merck veterinary manual. 8th ed. New Jersey (USA): Merck Co., Inc White House Station.

Moddie EW. 1965. Hypocalcaemia and hypomagnesaemia. Br Vet J. 121:338-342.

Mondal S, Prakash BS. 2003. Peripheral plasma progesterone concentration in relation to estrus expression in Sahiwal cows. Indian J Physiol Pharmacol. 47:111-114.

Nejra H, Josip K. 2012. Values of calcium, phosphorus and magnesium concentrations in blood plasma of cows in dependence on the 3 reproductive cycle and season. $\mathrm{J}$ Fac Vet Med Istanbul Univ. 38:1-8.

[NRC] Nutrient Requirements Council. 1984. Nutrient requirements of domestic animals. No. 6. Nutrient requirements of beef cattle. Washington DC (USA): NAS-NRC.

Olayemi FO, Oyewale JO, Fajinmi JL. 2001. Plasma electrolyte, protein and metabolite levels in Nigerian White Fulani cattle under two different management systems. Trop Anim Health Prod. 33:407-411.

Oltner R, Bergland B. 1983. Leukocytes packed cell volume, glucose, urea, calcium, inorganic phosphorus and magnesium in the blood of dairy cows. J Vet Med. 30:530-541.

Oser BL. 1965. Physiological chemistry. 14th ed. New York (USA): McGraw Hill Book Company.

Pearson H. 1964 Recent advances in our knowledge of milk fever. Vet Rec. 76:1442.

Puls R. 1981. Veterinary trace mineral deficiency and toxicity information. Information services. Agric, Canada, Ottawa, ON. Publ. no. 5139.

Qureshi MS. 1998. Relationship of pre and postpartum nutritional status with reproductive performance in NiliRavi buffaloes under the conventional farming system in NWFP, Pakistan (Thesis). [Punjab (Pakistan)]: University of Agriculture Faisalabad.

Radostits OM, Blood DC, Gay CC. 2000. Veterinary Medicine: A textbook of the diseases of cattle, sheep, goats, and horses. 8th ed. Philadelphia (USA): Saunders, Elseviers.

Rao LV, Pandey RS. 1982. Seasonal changes in plasma progesterone concentrations in buffalo cows (Bubalus bubalis). J Reprod Fertil. 66:57-61.
Rao TKS, Kumar N, Kumar P, Chaurasia S, Patel NB. 2013. Heat detection techniques in cattle and buffalo. Vet World. 6:363-369.

Roussel JD, Aranas TJ, Seybt SH. 1982. Metabolic profiles testing in Holstein cattle in Louisiana: Reference values. Am J Vet Res. 43:1658-1660.

Roussel JD, Beatty JF, Lee JA. 1977. Influence of season and reproductive status on peripheral plasma progesterone level in the lactating bovine. Int J Biometeor. 21:85-91.

Saied M. 2017. Some haematological and biochemical blood values in cattle diagnosed clinically as ephemeral fever in Qena governorate, Egypt. Int $\mathrm{J}$ Develop Res. 7:13432-13435.

[SAS] Statistical Analysis System. 2004. User's guide: Statistics, (ver. 9). Cary, North Caroline (USA): SAS Institute, Inc.

Singh A, Singh ONK. 2006. Blood biochemical and enzyme profile in oestrus and anoestrus heifers. Indian Vet J. 83:726-729.

Small JA, Charmley E, Rodd AV, Fredeen AH. 1997. Serum mineral concentrations in relation to estrus and conception in beef heifers and cows fed conserved forage. Can J Anim Sci. 77:55-62.

Tandle MK, Biradar US, Amanullah MD, Honnappogal SS, Kartikesh SM, Sonwane SD, Jagjiwanram. 1998. Blood biochemical profiles in cyclic and anestrus Deoni cows. Indian J Dairy Sci. 51:66-68.

Tegegne A, Entwistle KW, Mugerwa EM. 1993. Plasma progesterone and blood metabolite profiles in postpartum small East African Zebu cows. Trop Anim Helth Prod. 25:101-110.

Underwood EJ. 1981. The mineral nutrition of livestock. Bureau, London (UK): Commonwealth Agricultural.

Valee BL, Wacker WEC. 1976. The proteins. 2nd ed. New York (USA): Academic Press.

Widmar NJO, Wolf CA, 2008. Economic analysis of reproductive management strategies on us commercial dairy farms. J Dairy Sci. 91:4082-4091.

Yokus B, Cakir DU, Kanay Z, Toprak G, Uysal E. 2006. Effects of seasonal and physiological variations on the serum chemistry, vitamins and thyroid hormone concentrations in sheep. J Vet Med. 53:271-276. 